\title{
Social Enterprise in Small Hydropower (SHP) Owned by a Limited Liability Partnership (LLP) between a Food Cooperative and a Social Venture Company; a Case Study of the 20 kW Shiraito (Step3) SHP in Itoshima City, Fukuoka (Japan)
}

\author{
Zafar Alam $^{1}$, Yoshinobu Watanabe ${ }^{1}$, Shazia Hanif ${ }^{2}$, Tatsuro Sato ${ }^{3}$ (D) and Tokihiko Fujimoto ${ }^{4, *}$ \\ 1 Nakayama Iron Works Co., Ltd., Takeo 843-000, Japan; zafar786.jec@gmail.com (Z.A.); \\ watanabe@nakayamairon.co.jp (Y.W.) \\ 2 Department of Agricultural Engineering, Muhammad Nawaz Sharif University of Agriculture, \\ Multan 66000, Pakistan; agha_shaz@yahoo.com \\ 3 Faculty of Architecture and Civil Engineering, Kyushu Sangyo University, Fukuoka 813-8503, Japan; \\ sato@ip.kyusan-u.ac.jp \\ 4 School of Political Science and Economics, Meiji University, Tokyo 101-8301, Japan \\ * Correspondence: fujimoto@meiji.ac.jp; Tel.: +81-3-3296-2145
}

Citation: Alam, Z.; Watanabe, Y.; Hanif, S.; Sato, T.; Fujimoto, T. Social Enterprise in Small Hydropower (SHP) Owned by a Limited Liability Partnership (LLP) between a Food Cooperative and a Social Venture Company; a Case Study of the $20 \mathrm{~kW}$ Shiraito (Step3) SHP in Itoshima City, Fukuoka (Japan). Energies 2021, 14, 6727. https://doi.org/10.3390/ en14206727

Academic Editors: Tomasz Wegiel, Dariusz Borkowski and Wen-Hsien Tsai

Received: 15 September 2021 Accepted: 13 October 2021

Published: 15 October 2021

Publisher's Note: MDPI stays neutral with regard to jurisdictional claims in published maps and institutional affiliations.

Copyright: (c) 2021 by the authors. Licensee MDPI, Basel, Switzerland. This article is an open access article distributed under the terms and conditions of the Creative Commons Attribution (CC BY) license (https:// creativecommons.org/licenses/by/ $4.0 /)$.

\begin{abstract}
There was an unprecedented growth of SHP (small hydropower) in Japan during recent years because the government has provided a high FIT (USD 0.32/kWh) for SHP development projects of less than $200 \mathrm{~kW}$. The public and private sectors are committed to harnessing this natural energy to achieve the renewable energy goal as well as to improve local communities social and economic conditions. This paper will discuss about renewable energy initiatives by a food corporation enterprise (FCOOP) based in Fukuoka prefecture of Japan to reduce their net carbon emissions. A detailed approach for social enterprises-based SHP development has been discussed which will be a role model concept for other social enterprises in Japan and in the world that are willing to reduce $\mathrm{CO}_{2}$ emissions. Also, this kind of project connects urban stake holders with local community where resources are available and it leads to development of the local community living standards. As a demonstrated example, a case study of a $20 \mathrm{~kW} \mathrm{SHP} \mathrm{installed} \mathrm{in} \mathrm{Japan} \mathrm{by} \mathrm{a} \mathrm{FCOOP} \mathrm{has}$ been discussed.
\end{abstract}

Keywords: small hydropower; SHP; renewable energy; FIT; social enterprise; food cooperative; limited liability partnership; LLP; community business; community-based resource management; sustainable development; SDGs

\section{Introduction}

In modern life, electricity intervention has become one of the basic needs and a driving force. However, in some remote areas, this facility is inaccessible, and according to an estimation about 1.3 billion rural residents do not have access to electricity in the world [1]. There are many difficulties which must be endured by the community due to energy crises, e.g., lack of employment opportunities, hindered access to healthcare and education [2,3]. In addition, current sources of electricity generation cause high $\mathrm{CO}_{2}$ and greenhouse gas emissions (GHG). Climate change is the other challenge the world faces; it involves extreme weather, drought, and irregular rainfall patterns. Thermal power generation using fossil fuels has a significant impact on global warming [4]. To mitigate this problem, it was recommended that fossil fuels be replaced by renewable energy sources.

Among renewable energy options, small hydropower (SHP) is gaining more preference as its construction has small effects on water bodies. SHP provides high potential, while requiring less investment, and their speedy construction and low cost generates quick revenue as well as clean energy $[5,6]$. The United Nations Industrial Development 
Organization (UNIDO) has been publishing its "World Small Hydropower Development Report" since 2013, and analyzed case studies on the economic benefit and social contribution of SHP development in the 2019 report. Under this case study, a good representation of SHP development in the world has been discussed. According to WSHPDR 2019, SHP development in the world can categorized as follows:

(a) SHP for productive use (this kind of SHP can create new opportunities for local businesses by providing power infrastructure; the Sarhad Rural Support Programme in Pakistan and the Gura SHP development in Kenya and the Oitake SHP development in Japan are the demonstrated examples). (b) Incentive policies for SHP development (this framework would encourage the use of SHP and make the sector more attractive for investment. SHP in Panama is a demonstrated example). (c) Green SHP (this model is based on ecological sustainability; this kind of SHP development has been demonstrated in China and Australia) [7].

Furthermore, many studies focused on SHPs as important renewable energy sources have been done, such as SHP for social and community development (this initiative of SHP can create conditions for communities to improve their quality of life and create employment. A model case of a community-owned SHP in Japan is a demonstrated example [8]. However SHP projects often faced ignorance that results in a lack of investment. Local community organizations play important roles in the development of distributed local energy $[9,10]$. These kinds of organization should be involved in the planning, fundraising, design, implementation, and governance of energy related projects to make them economically, ecologically and energy efficient [11]. For example, in Europe, Community Energy Systems (CES) has been formed which is responsible for providing the energy requirement of local community from renewable energy sources. In this effort, CES comes forward for planning, design, implementation, and governance of integrated energy systems at the community level [12]. Similarly, in Japan some cooperatives (especially food cooperatives or FCOOPs) buy energy either from a $100 \%$ renewable source or a " $30 \%$ renewable and $70 \%$ others" sources and sell it to the consumer at discounted rates to promote renewable energy. Many other communities have started implementing sustainable energy developments around the world due to favorable and subsidized policies devised by the respective governments [13]. These kinds of social enterprises made many efforts to reduce greenhouse gas emissions and support renewable society. It provides energy access to rural communities and helps to identify the stakeholders and agency, resource dependency and ecology. These attributes construct the typology of stakeholders, propositions concerning their salience to firm managers, and research and management implications [14].

In this paper, a detailed case study of a social enterprises-based SHP development model will be discussed from the points of view on "net zero emission" of a cooperative business and "clean environment for the next generation".

The remainder of the article is divided as follows; Section 2 will discuss social enterprises' initiatives to develop SHP through a limited liability business partnership (LLP) and the details of a case study concerning the Shiraito (Step3) SHP development. Section 3 will discussed the installation process of the Shiraito (Step3) SHP by the LLP as a social business. In the discussion and conclusions section (Sections 4 and 5), a brief discussion about social enterprises' cause and motives toward SHP (or renewable energy development) is presented, and the case report concluded.

\section{Business Model: Social Enterprises Initiatives for the Shiraito SHP Development}

\subsection{Location and Outline}

This case report focuses on the Shiraito community in the Shiraito district of Itoshima city on Kyushu Island of the south part in Japan. The population of this district is approximately 111 people ( 49 males, 62 females) living in 39 houses. The main source of income in the district is agriculture. The "Shiraito Falls 1, 2 and 3 Dream Project" was started in 2011 as a collaborative project between Itoshima City and Kyushu University. 
Figure 1 presents the location of these three projects. Step 1 was to restore the wooden water wheel at Shiraito Falls and handcraft a power generation system with students from Kyushu University. The power plant in Step 2 was developed by Kyushu University professors and the Itoshima City Office. It was started in 2012 and completed in 2014. Two turbines have been installed which produce a total of $15 \mathrm{~kW}$. It is located about $200 \mathrm{~m}$ downstream of Shiraito Falls [15].

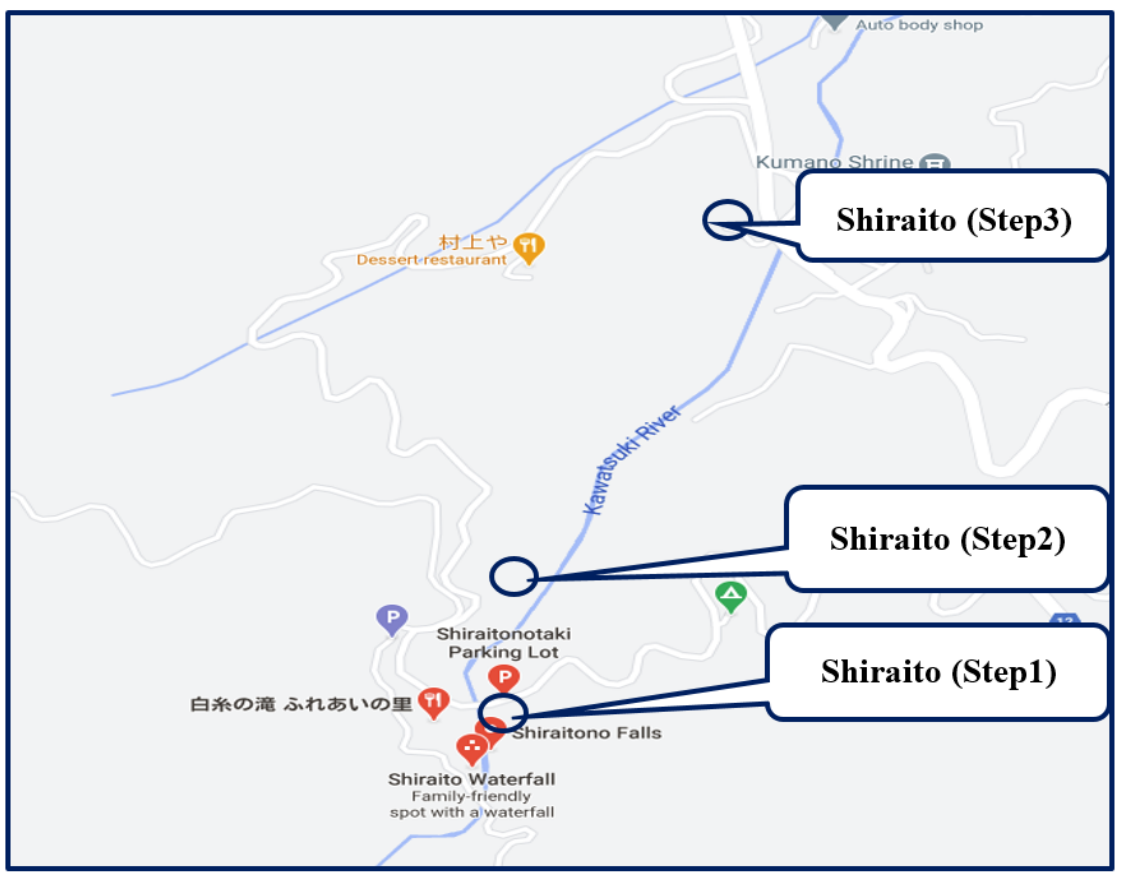

Figure 1. Location of the Shiraito Falls 1, 2 and 3 Dream Projects in Itoshima city (Source: Google Maps).

The Step3 is the newest power plant, located near the entrance to the Shiraito promenade. This project was developed by the collaboration of FCOOP and a social venture company from Kyushu University, called River Village (Rivi). The plant's generation capacity is $12 \mathrm{~kW}$ (FIT qualification: $19.9 \mathrm{~kW}$ ) and it started generation in June 2019. It is estimated to generate a total of $66 \mathrm{MWh} /$ year.

\subsection{Business Model}

Many private investors are looking to invest in the renewable energy sector to get carbon credits. If a company is involved in a business where GHG emissions occur, they need to buy carbon credits to achieve net zero emissions [16]. These companies are investing directly in renewable energy business, it helps to neutralize their $\mathrm{CO}_{2}$ emissions and at the same time investors get the benefit of a high FIT on renewable energy by selling electricity.

In this case report of Shiraito SHP also, a similar model has been adopted where a food cooperative (FCOOP) based in Fukuoka prefecture of Japan has invested in SHP development. The food corporation company uses LPG, gasoline and electricity to run its business. It emits a large amount of $\mathrm{CO}_{2}$ to the environment. To neutralize these $\mathrm{CO}_{2}$ emissions, the FCOOP is working on a number of initiatives such as waste food recycling, eco-friendly product production, and renewable energy investment, etc. To reduce the burden of its activities on the environment, it has invested in SHP for the first time with the aim of reducing $\mathrm{CO}_{2}$ emissions to the environment and provide a green, sustainable and pollution free environment for the next generation. The income earned by selling electricity will be partly used to develop the energy production area.

Shiraito SHP was developed by a new social business enterprise called "Seeds of energy", which is a Limited Liability Partnership (LLP) between the FCOOP and Rivi. Both entities came together and each invested $50 \%$. 
Figure 2 presents the business model for the development of the Shiraito SHP. This LLP will develop Shiraito (Step3) SHP and the other sources of energy that will aim to improve the local community lifestyle.

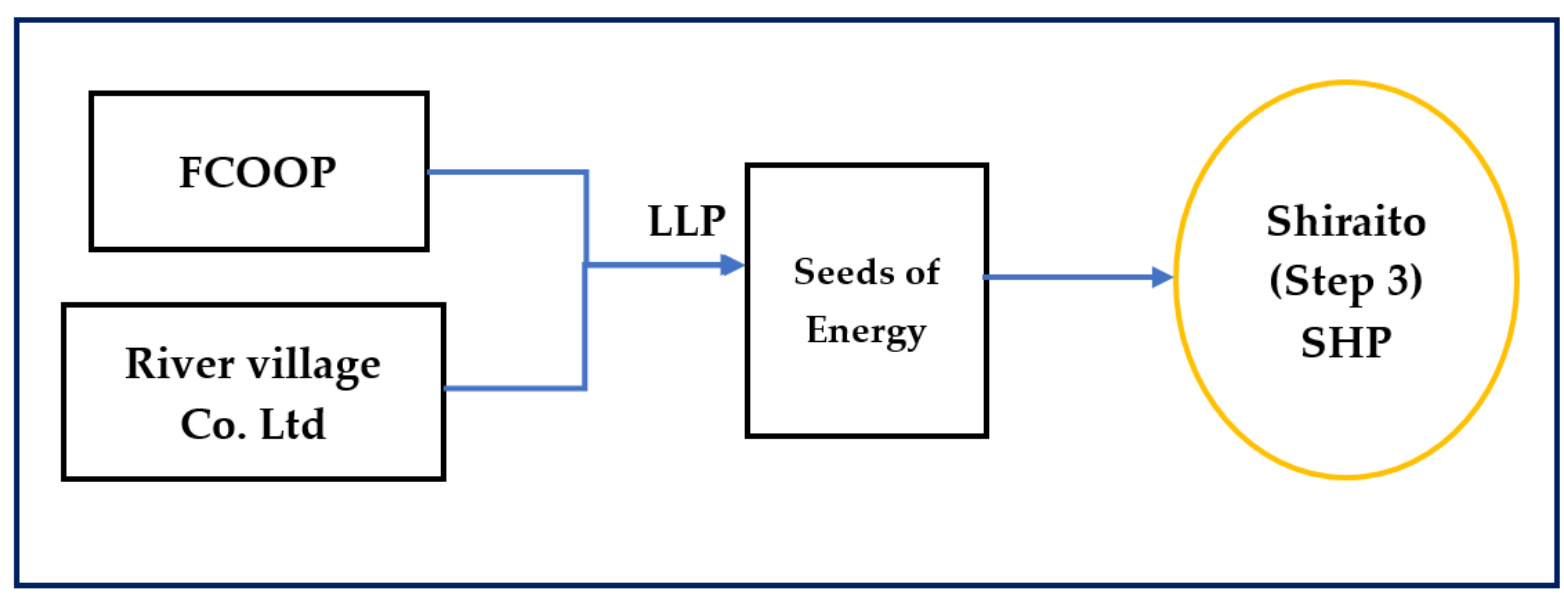

Figure 2. Social business model for the Shiraito (Step3) SHP.

The next challenge in Shiraito (Step3) SHP was to execute the project, to select the suitable turbine and other machines. Nowadays, it is hard to find turbine makers in Japan especially companies which make micro hydroturbines [17]. The reason for this is the high cost of manufacturing and the lack of business opportunities. In the previous project, Nakayama Iron Works Co Ltd. which is located in Takeo City, Saga, provided the electromechanical equipment, and installation of the machines for Shiraito (Step2) SHP [15]. The consultant and civil works activities had also been provided by Itoshima city for Shiraito (Step2) SHP [12].

\section{Technical Details of Shiraito (Step3) SHP}

Figure 3 shows the SABO dam. For the Shiraito (Step3) SHP, it works as a forebay tank. The purpose of the forebay tank is to stabilize the gross head of water available at the site and provide a specific amount of flow for power generation. Figure $3 \mathrm{~b}$ presents the powerhouse which is made up of cheap and locally available material. Figure $3 \mathrm{c}$ presents the equipment installed inside the powerhouse. Some electrical and control equipment has been installed in a hut beside the powerhouse. A cross flow turbine connected to a generator, control panel, resistor, AC reactor and transformer has been installed inside a hut beside the powerhouse.

Based on the site data in Table 1, a crossflow turbine has been selected and a costeffective hydropower system has been proposed. The installed turbine is a Swiss designed cross flow T-15 turbine manufactured in Indonesia, and the other electric and control equipment are made in Japan.

Table 1. Site details.

Location: Shiraito District, Itoshima City, Fukuoka Prefecture, Japan

-8,191,154 (coordinate: 33.486652, 130.178755)

Installation date: June 2019

Design flow (Qd): $0.1 \mathrm{~m}^{3} / \mathrm{s}$

Design net head (Hn): $25.2 \mathrm{~m}$

Table 2 lists technical information about Shiraito (Step3) SHP. The total output of system design is $12 \mathrm{~kW}$ (FIT qualification: $19.9 \mathrm{~kW}$ ). A yearly energy generation was estimated as 66 MWh when the turbine runs for 350 days in a year with a 70\% utilization factor. The total construction cost was approximately USD 206,200 and yearly revenue was 
estimated at USD 21132/year, which is calculated as total energy generation in year (in $\mathrm{kWh}$ ) multiplied by the prevailing FIT (USD 0.32).
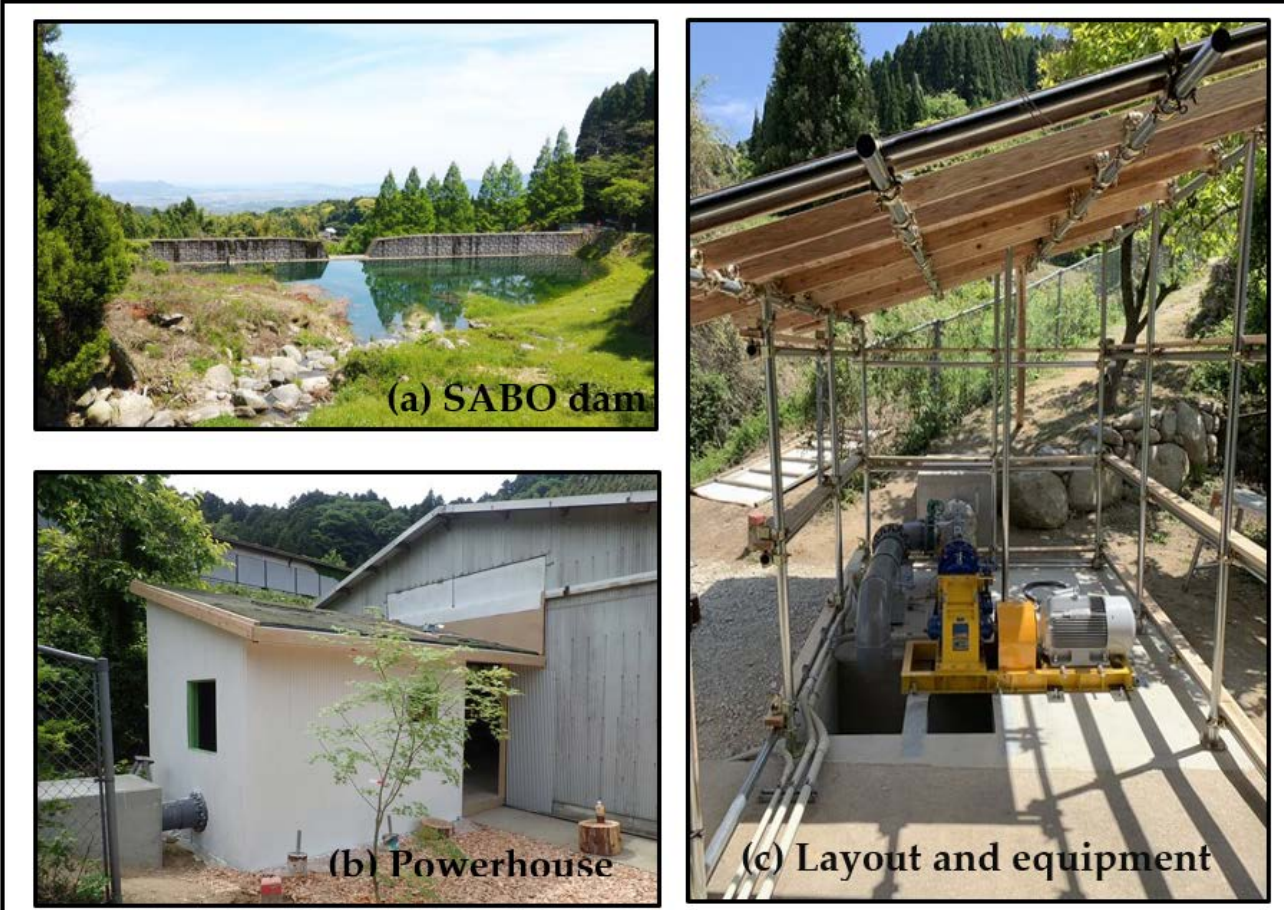

Figure 3. An illustration of the Shiraito (Step3) SHP site.

Table 2. Technical details of Shiraito (Step3) SHP.

\begin{tabular}{cccc}
\hline S. no & Items & Values & Remarks \\
\hline 1. & Turbine output & $18.5 \mathrm{KW}$ & $\begin{array}{c}\text { Cross-flow(T-15) } \\
\text { Asociasi Hidro } \\
\text { Bandung, Indonesia } \\
\text { FIT qualification: }\end{array}$ \\
2. & Design output & $12 \mathrm{~kW}$ & $19.9 \mathrm{~kW}$ \\
3. & Energy generation & $66 \mathrm{MWh}$ & Estimated \\
4. & Total investment & USD 206,200 & Approximately \\
5. & FIT & USD $0.32 / \mathrm{kWh}$ & Japan \\
6. & Expected income & USD $21,132 /$ Year & Roughly \\
7. & Present output & $12.7 \mathrm{~kW}$ & 8 April 2021 \\
\hline
\end{tabular}

\section{Economic Analysis}

The total construction cost of this project was USD 206,200, which is approximately USD 17,180/kW. Figure 4 shows the investment model of Shiraito (Step3) SHP. The FCOOP and Rivi had each invested $50 \%$ of the funding of the LLP. The FCOOP invested its own money and Rivi borrowed the money from a bank for the period of 10 years at an interest rate of $0.7 \%$. 


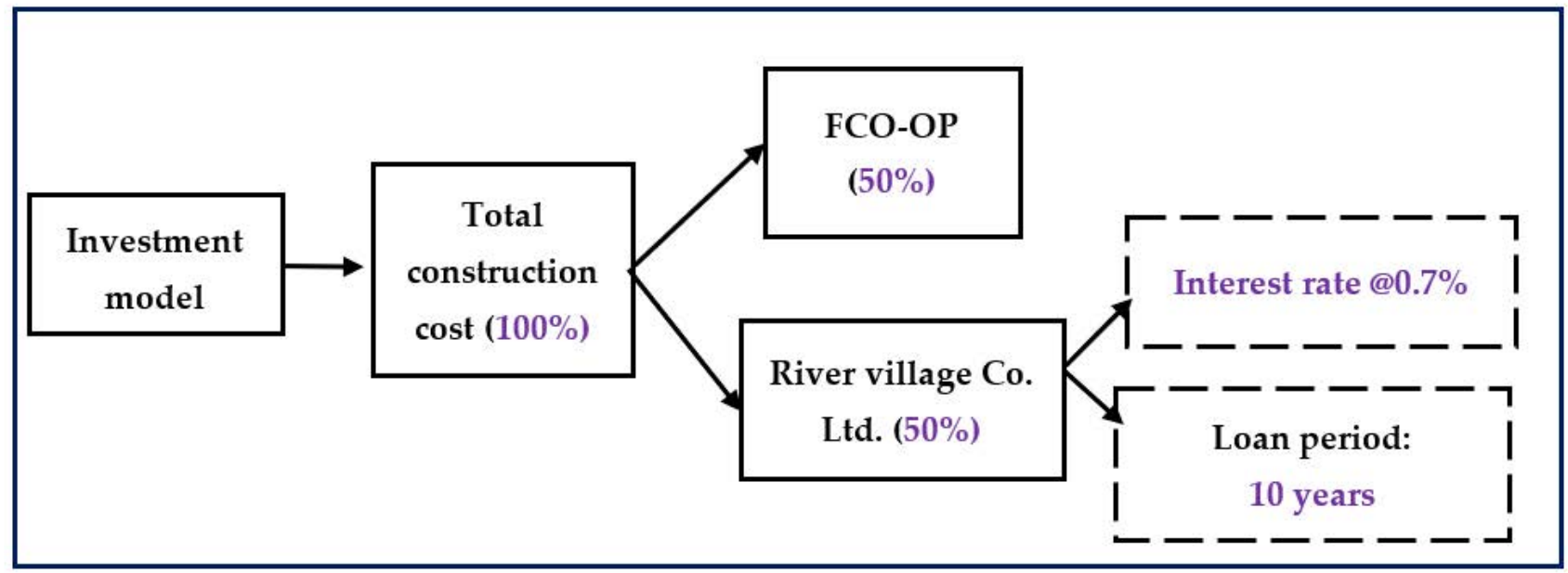

Figure 4. Investment Model of the Shiraito (Step3) SHP.

Table 3 gives a brief summary of the construction and operation costs of the Shiraito (Step3) SHP. The total construction cost was USD 209,520(17,460 USD/kW) and the running/operation cost was USD 56,380 (2,820 USD/Year).

Table 3. Construction cost and Running cost of Shiraito (Step3) SHP.

\begin{tabular}{|c|c|c|c|c|c|}
\hline \multicolumn{2}{|r|}{ Facility Name } & Unit Cost (USD) & \multicolumn{2}{|c|}{ No. of Unit } & Sub Total \\
\hline \multicolumn{6}{|c|}{ 1. CONSTRUCTION COST } \\
\hline (1) & Mechanical equipment cost & \multirow{4}{*}{$\$ 109,500$} & 1 & Set & \multirow{4}{*}{$\$ 109,500$} \\
\hline (2) & Electrical equipment's cost & & 1 & Set & \\
\hline (3) & Control panel cost & & 1 & Set & \\
\hline (4) & IoT cost & & 1 & Set & \\
\hline (5) & Civil engineering cost & $\$ 47,500$ & 1 & Set & $\$ 47,500$ \\
\hline (6) & Project management cost & $\$ 36,200$ & 1 & Set & $\$ 36,200$ \\
\hline \multirow{2}{*}{ (7) } & Others (architect, electric works etc.) & $\$ 13,000$ & 1 & Set & $\$ 13,000$ \\
\hline & Subtotal & & & & $\$ 206,200$ USD \\
\hline \multicolumn{6}{|c|}{ 2. RUNNING COST (for 20 years period) } \\
\hline (1) & Equipment replacement cost (in 20 years) & $\$ 950$ & 20 & Times & $\$ 19,000$ \\
\hline \multirow{3}{*}{ (2) } & Inspection cost & & & Times & \\
\hline & (A) Yearly inspection cost & $\$ 1150$ & 16 & Times & $\$ 18,400$ \\
\hline & (B) 5 yearly inspection cost & $\$ 2400$ & 4 & Times & $\$ 9600$ \\
\hline \multirow{3}{*}{ (3) } & Miscellaneous & $\$ 475$ & 20 & Times & $\$ 9500$ \\
\hline & Subtotal & & & & $\$ 56,500$ \\
\hline & Total Investment (20 years) & & & & $\$ 262,700$ USD \\
\hline
\end{tabular}

During the planning of this case, a cash flow analysis was done to check the project's economic viability. The result of cash flow analysis is shown in below and in Figure 5. In Japan, if the IRR of a SHP project is greater than $5 \%$, it is assumed that it will be beneficial. Since, an IRR of $6 \%$ was calculated for Shiraito (Step3) SHP, it was assumed to be beneficial. It is found from the cumulative cash flow graph that the breakeven point will be achieved in approximately 11.5 years. 


\section{Cumulative cash flow}

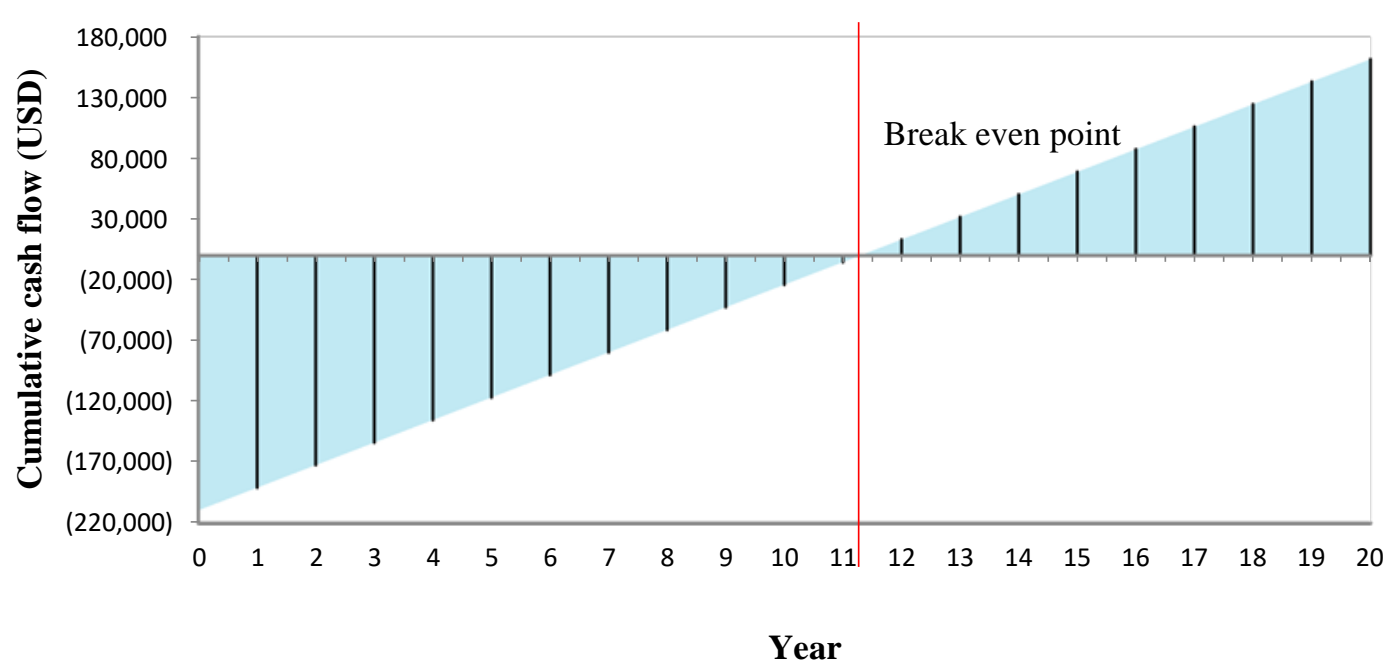

Figure 5. Cumulative cash flow vs. year graph.

\section{Discussion}

As the article mentioned before, the installation of the Shiraito (Step3) SHP was an initiative by the FCOOP to reduce the $\mathrm{CO}_{2}$ burden of the environment by introducing renewable energy in the grid. Also, a part of the income will be used to develop the local community nearby the powerhouse. The benefits of installing this kind of SHP can be categorized as follows:

\subsection{Environment Perspective}

From an environmental perspective point of view, the Shiraito (Step3) SHP initiative contributes to the FCOOP's efforts to promote clean energy sources and to achieve its wider sustainable development goals (SDGs), as the project promotes renewable energy generation by converting unused available water into a useful product without consuming or affecting it [18-20].

In case of particular SDGs, the Shiraito (Step3) SHP contributes to the targets of SDGs 7,8 and 13 . With respect to $\mathrm{CO}_{2}$ reduction, since, per $\mathrm{kWh}$ of electricity generated from SHP reduces $0.480 \mathrm{~kg} \mathrm{CO}_{2}$, the $66 \mathrm{MWh}$ of electricity generated annually by the Shiraito (Step3) SHP will lead to a reduction of approximately 32 tons of $\mathrm{CO}_{2}$ per year.

\subsection{Social Perspective and Community Contribution}

From a social perspective point of view, this kind of project uses local resources during the construction period which helps grow local companies (civil works and consultants). In this case, the civil engineering was done by a local company and local resources and laborers were used to build the powerhouse. A small amount of land has been loaned to install the equipment [21].

The other social contribution of Shiraito (Step3) SHP was for the purpose of childrens' education and as a demonstration site for the community to learn about SHP (Figure 6). Also, a part of income earned by selling electricity will be used to develop the Shiraito community which is one of the most prominent targets of the SHP in the future.

As seen in the Figure 6, local people and children of Shiraito (Step3) SHP helped during the construction of the powerhouse. During the planning period, a workshop has been organized where children made a small model of a water turbine and generator set, and demonstrated the actual power generation by flowing a small steam of water. 


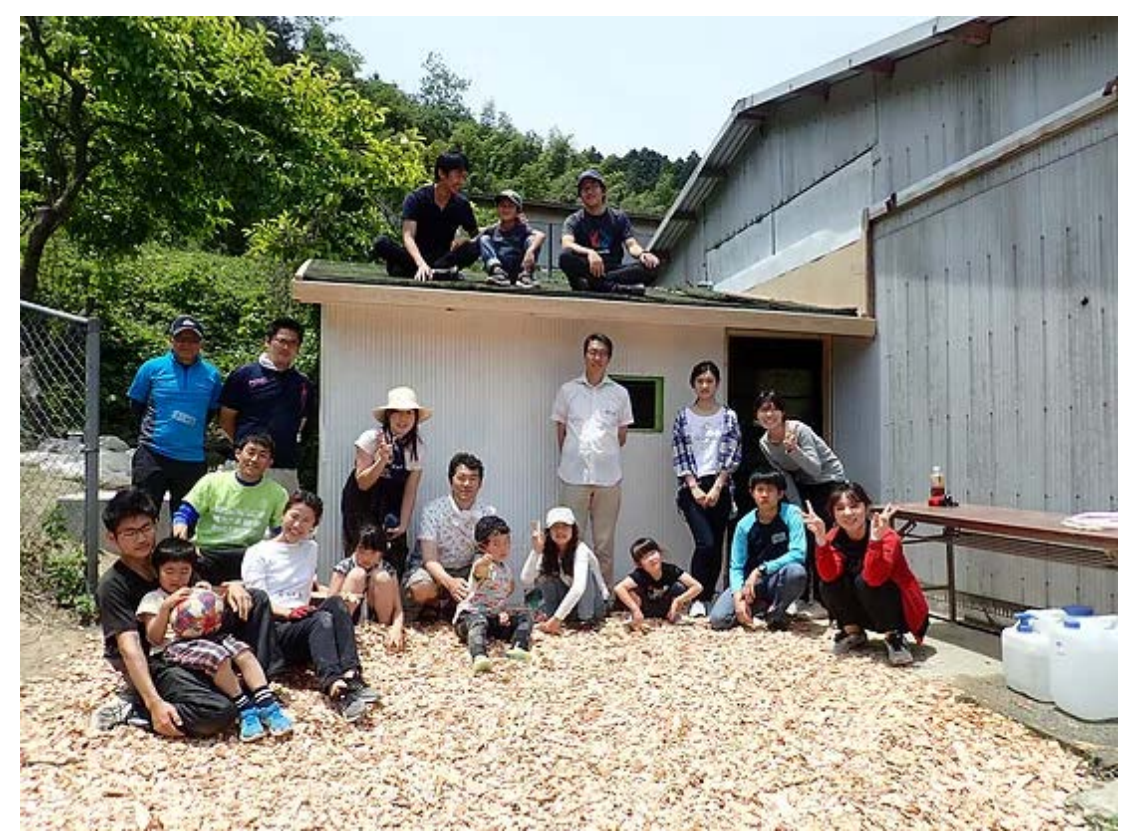

Figure 6. Local people and children during the construction of the Shiraito (Step3) SHP.

\subsection{Economic Perspective}

Since the Japanese government is paying a high FIT for micro hydropower projects (USD 0.32/kWh for SHP projects of less than $200 \mathrm{~kW}$ ), this kind of SHP project provides a high return on investment. Shiraito (Step3) SHP was installed and started operating in June 2019. It continues to run well until now without any major hurdle.

Figure 7 shows the instantaneous real time data of the plant. This picture was taken on 8 April 2021. The output during the rainy season or rich water period was approximately $12 \mathrm{~kW}$, and during the lean period it is about $8 \mathrm{~kW}$. The total energy generated per the data taken on 8 April 2021 is $145.8 \mathrm{MWh}$. The real time out at that time was $8.06 \mathrm{~kW}$ in the grid side and $8.8 \mathrm{~kW}$ after generator. The other important parameters are also shown in the real time monitoring panel. The generated energy is sold to the National Grid Power Company in the Kyushu area at the rate of USD 0.32/ kWh according to the FIT scheme. The gross income as per the above data is USD 46,783 , which is approximately $22.5 \%$ of the total construction cost.

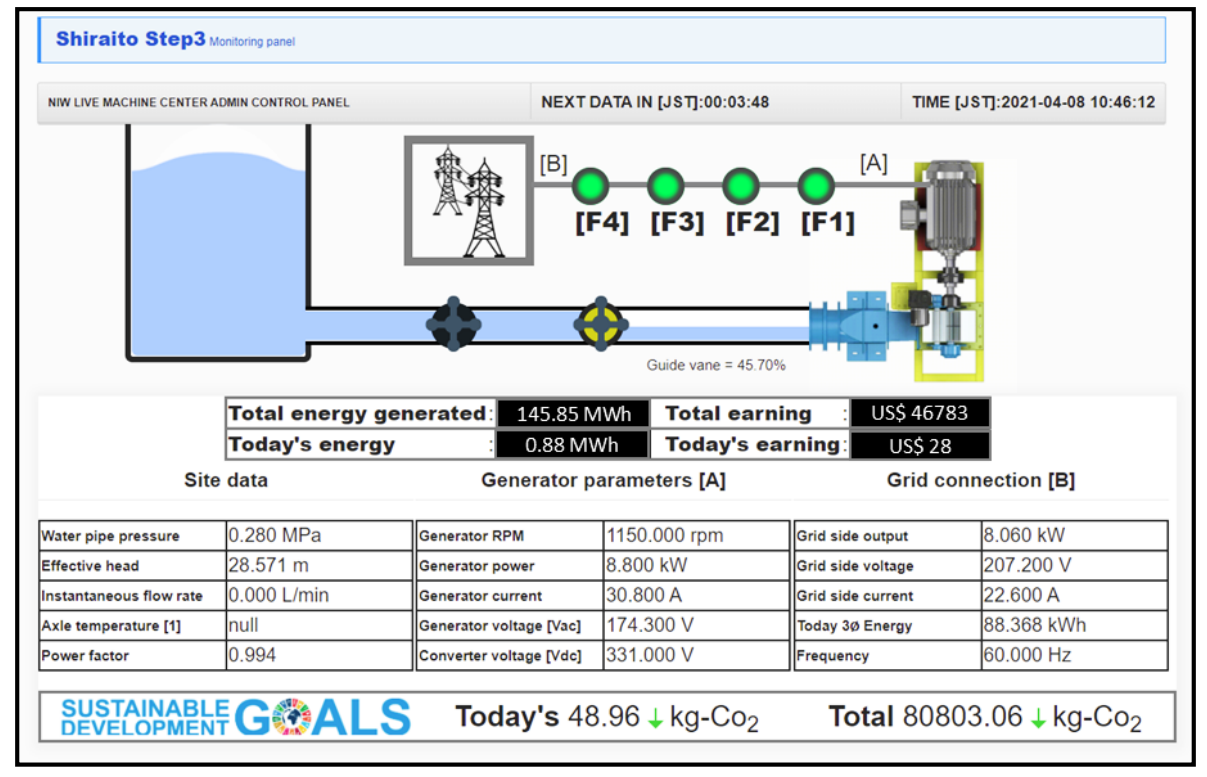

Figure 7. Data monitoring display of the Shiraito (Step3) SHP. 
As the paper discussed before (Figure 5), initially the breakeven period of this SHP was estimated to be about 11.5 years, but due to the high efficiency system and water availability throughout the year, the plant produced 145 MWh in just a 1 year and 9 month period. The plant thus produced $25 \%$ more income than expected. If it continues running as in the past 2 years, it will shorten the project return period to approximately 9 years and the IRR will be increased to $9.5 \%$.

\section{Conclusions}

In this case study, it is concluded that SHP development projects can benefit the local community, investors, a country's renewable energy target to reduce carbon footprint and enterprises to achieve their net carbon emission targets. This kind of SHP project helps to integrate local communities with urban stakeholders (like FCOOP) and form a network of investors, manufacturers and users. This network can harness not only hydropower in the community, but also the other renewable energy sources such as solar, biomass, etc.

The paper has discussed social enterprises' (such as food corporations) renewable energy promotion initiatives that emphasize ties with the local community, such as reducing the environmental burden of its activities and supporting the local community. The food corporation enterprise discussed in this paper are also putting efforts into creating and spreading renewable energy use and environmentally friendly products. The environmental activities that the FCOOP undertook are "low-carbon living community that does not rely on nuclear power plants", "promotion of products aiming for a sustainable society that coexists with nature" and "recycling-type living and community that makes the best use of resources".

It also forms a relationship bridge between urban consumers and the energy production area. This also provides a learning opportunity for community people, children and staff so that they can feel closer to renewable energy and its usage in the community (Rivi's action).

This project helped to boost the local community development and helped to grow the local employment and provide new business opportunity for a local civil engineering company and consultant.

Installing an SHP helps economically, socially and environmentally. This case report has given a practical SHP demonstration by social enterprises for the purpose of carbon reduction and net zero emission targets. It can be a model for the other enterprises and similar enterprises worldwide to reduce their net carbon emissions and provide a clean environment for the next generation.

Author Contributions: Conceptualization, Z.A. and T.F.; methodology, Z.A.; software, S.H.; validation, T.F., S.H. and Y.W.; formal analysis, S.H.; investigation, Z.A.; resources, T.F.; data curation, Z.A., T.F. and Y.W.; writing-original draft preparation, Z.A. and S.H.; writing-review and editing, T.F. and S.H.; visualization, Y.W.; supervision, T.F. and T.S.; project administration, T.S. and Y.W.; funding acquisition, T.F. All authors have read and agreed to the published version of the manuscript.

Funding: This research was supported by JSPS KAKENHI (Grant-in-Aid for Early-Career Scientists) Grant Number 18K14538, Tokihiko Fujimoto.

Institutional Review Board Statement: Not applicable.

Informed Consent Statement: Not applicable.

Data Availability Statement: Not applicable.

Conflicts of Interest: The authors declare no conflict of interest.

\section{References}

1. SE4ALL. Sustainable Energy for All. 2014. Available online: http://www.se4all.org/our-vision/our-objectives/universalenergy / (accessed on 3 January 2014).

2. Zimon, D.; Tyan, J.; Sroufe, R. Drivers of sustainable supply chain management: Practices to alignment with unsustainable development goals. Int. J. Qual. Res. 2019, 14, 219-236. [CrossRef] 
3. Tokihiko Fujimoto. World Small Hydropower Development Report 2016; United Nations Industrial Development Organization (UNIDO) and International Center on Small Hydro Power (ICSHP): Viena, Austria; Hangzhou, China, 2016; pp. 415-419.

4. Strezov, V.; Cho, H.H. Environmental impact assessment from direct emissions of Australian thermal power generation technologies. J. Clean. Prod. 2020, 270, 122515. [CrossRef]

5. Cheng, H. Utilization of small hydropower resources with promotion of new countryside construction. China Water Resour. 2006, 14, 17-18.

6. Paish, O. Small hydro power: Technology and current status. Renew. Sustain. Energy Rev. 2002, 6, 537-556. [CrossRef]

7. World Small Hydropower Development Report 2019 (Case Study); United Nations Industrial Development Organiza-tion (UNIDO) and International Center on Small Hydro Power (ICSHP). Available online: https: / /www.unido.org/sites/default/ files / files / 202002/WSHPDR\%202019\%20Case\%20Studies.pdf\#page=37 (accessed on 4 October 2021).

8. Alam, Z.; Watanabe, Y.; Hanif, S.; Sato, T.; Fujimoto, T. Community-Based Business on Small Hydropower (SHP) in Rural Japan: A Case Study on a Community Owned SHP Model of Ohito Agricultural Cooperative. Energies 2021, 14, 3349. [CrossRef]

9. Yoshihiro, Y. The role of community energy in renewable energy use and development. Renew. Energy Environ. Sustain. 2016, 1, 18-22. [CrossRef]

10. Quest. Building Smart Energy Communities: Implementing Integrated Community Energy Solutions; Quality Urban Energy Systems for Tomorrow: Ottawa, ON, Canada, 2012.

11. United Nation. United Nations Foundation. Available online: http:/ /www.unfoundation.org/what-we-do/issues/energy-andclimate/clean-energy-development.html. (accessed on 3 January 2014).

12. Takagi, M.; Watanabe, Y.; Ikematsu, S.; Hayashi, T.; Fujimoto, T.; Shimatani, Y. 3D-printed Pelton Turbine: How to Produce Effective Technology Linked with Global Knowledge. Energy Procedia 2014, 61, 1593-1596. [CrossRef]

13. Hamwi, M.; Lizarralde, I.; Legardeur, J. Demand response business model canvas: A tool for flexibility creation in the electricity markets. J. Clean. Prod. 2021, 282, 124539. [CrossRef]

14. Mitchell, R.K.; Agle, B.R.; Wood, D.J. Toward a theory of stakeholder identification and salience: Defining the principle of who and what really counts. Acad. Manag. Rev. 1997, 22, 853-886. [CrossRef]

15. Yoshinobu, W.; Youichi, K.; Mina, T.; Tokihiko, F.; Yukihiro, S. Re-Build up Small Scale Hydropower Technologies in Japan by Local Industrial Power. In Proceedings of the International Conference on Hydropower for Sustainable Development, Dehradun, India, 5-7 February 2015; pp. 235-238.

16. Agorasti Toka, S.C.; Lenny, K.; Victor, G.S. Chapter 8 Carbon Footprint Management for Food Supply Chains an Integrated Decision Support System. In Supply Chain Management for Sustainable Food Networks; Eleftherios, I., Dionysis, B., Dimitrios, V., Dimitrios, A., Eds.; John Wiley \& Sons, Inc.: Hoboken, NJ, USA, 2015; pp. 205-231. [CrossRef]

17. Watanabe, Y.; Alam, Z.R.R.; Okajima, K.; Yamamoto, S.; Faisal, R.; Kumar, A.; Fujimoto, T. World Small Hydropower Development Report 2019 Case Studies; United Nations Industrial Development Organization (UNIDO) and International Center on Small Hydro Power (ICSHP): Vienna, Austria; Hangzhou, China, 2019; pp. 37-40.

18. Dee, N.; Baker, J.; Drobny, N.; Duke, K.; Whitman, I.; Fahringer, D. An environmental evaluation system for water resource planning. Water Resour. Res. 1973, 9, 523-535. [CrossRef]

19. Botelho, A.; Ferreira, P.; Lima, F.; Costa Pinto, L.M.; Sousa, S. Assessment of the environmental impacts associated with hydropower. Renew. Sustain. Energy. Rev. 2017, 70, 896-904. [CrossRef]

20. Schramm, M.P.; Bevelhimer, M.S.; DeRolph, C.R. A synthesis of environmental and recreational mitigation re-quirements at hydropower projects in the United States. Environ. Sci. Policy 2016, 61, 87-96. [CrossRef]

21. Tokihiko, F.; Kazuki, K. Community-Led Micro-Hydropower Development and Landcare: A Case Study of Networking Activities of Local Residents and Farmers in the Gokase Township (Japan). Energies 2019, 12, 1033. [CrossRef] 